\title{
PERANAN POKOK-POKOK MANAJEMEN SISTEM INFORMASI PENDIDIKAN \\ (MSIP) PADA ORGANISASI PENDIDIKAN
}

Yusti Rahmi S2 AP (18147015)

Email: rahmiyusti861@gmail.com

Universitas Negeri Padang

\begin{abstract}
An educational organization will carry out operating functions that must be run within the organization to achieve the objectives of the education itself. Operational functions in educational organizations include accounting / financial operations, staffing, academic / curriculum functions, office administration, teaching and learning activities, buildings and spaces, libraries, alumni.

To carry out these operational functions, management needs to be needed, where of course the management functions must run well. Management functions that must be run in moving the operating function to achieve goals that are expected to at least include the functions of planning, organizing, staffing, directing, evaluating, coordinating, and budgeting.

Management of Educational Information Systems (MSIP) is a system designed for management needs in an effort to support management functions and activities in an educational organization. Data types and operating functions are tailored to the needs of management.
\end{abstract}

The Educational Information Management System (MSIP) includes:

a. Accounting information system / Keuan bro in educational organizations

b. Student Information Systems in educational organizations

c. Academic Information System / Curriculum in educational organizations

d. Student Centered Learning through e-Learning in educational organizations

e. Library information system in educational organizations.

Keyword: MSIP,Accounting information system, Student Information System, Academic Information System, Student Centered Learning, and Library information system.

\section{Latar Belakang}

Suatu organisasi pendidikan akan menjalankan fungsi-fungsi operasi yang harus berjalan dalam organisasi tersebut untuk mencapai tujuan dari penyelenggaraan pendidikan itu sendiri. fungsi-fungsi operasi dalam organisasi pendidikan meliputi fungsi operasi akuntansi/ keuangan, kepegawaian, akademik/Kurikulum, administrasi perkantoran, proses kegitan belajar mengajar, gedung dan ruang, perpustakaan, alumni.

Untuk menjalankan fungsi-fungsi operasi tersebut dibutuhkan manajemen di mana sudah barang tentu fungsi-fungsi manajemennya harus dapat berjalan dengan baik. Fungsi-fungsi manajemen yang harus berjalan dalam menggerakan fungsi operasi untuk mencapai tujuan yang diharapkan sekurang-kurangnya meliputi fungsi planning, organizing, staffing, directing, evaluating, coordinating, dan budgeting.

Fungsi menajemen memiliki tingkat kompleksitas yang tinggi dan tingkat relasional yang kompleks antar fungsi operasi ketika harus menjalankan fungsi operasi tersebut yang di bangun dalam organisasi pendidikan. Ketika fungsi operasi dalam organisasi berjalan sesuai fungsi manajemen, maka akan terjadi lalulintas 
data dan informasi yang saling terkait dan saling membutuhkan sehingga tingkat kompleksitas relasional antar fungsi tersebut kelihatan sekali.

$$
\text { Kompleksitas relasional data dan }
$$

informasi tersebut meliputi tahap-tahap pengumpulan data, klasifikasi data, pengolahan data supaya berubah bentuk, sifat, dan kegunaan menjadi informasi, interpretasi informasi, penyimpanan informasi, penyampaian informasi atau transmisi kepada pengguna dan penggunaan informasi untuk kepentingan manajemen organisasi.

Tahapan kompleksitas relasional data dan informasi memungkinkan ditempuhnya delapan tahap penting dalam penanganan informasi, yaitu penciptan informasi, pemeliharaan saluran informasi, transmisi informasi, penerimaan informasi, penyimpanan informasi, penelusuran informasi, penggunaan informasi dan penilaian kritis serta umpan balik. Tahap-tahap tersebut menjadi sebuah bentuk manajemen sistem informasi pendidikan.

Manajemen Sistem Informasi Pendidikan (MSIP) adalah sistem yang didisain untuk kebutuhan manajemen dalam upaya mendukung fungsi-fungsi dan aktivitas manajemen pada suatu organisasi pendidikan. Jenis data dan fungsi-fungsi operasi disesuaikan dengan kebutuhan manajemen.

\section{Rumusan Masalah}

Dari uraian tersebut di atas dapat disebutkan bahwa wilayah garapan/pokok-pokok Manajemen Sistem Informasi Pendidikan (MSIP) meliputi: a. Bagaimana Sistem informasi Akuntansi/Keuangan dalam organisasi pendidikan?

b. Bagaimana Sistem Informasi Kepegawaian dalam organisasi pendidikan?

c. Bagaimana Sistem Informasi Akademik/Kurikulum dalam organisasi pendidikan?

d. Bagaimana Student Centered Learning melalui e-Learning dalam organisasi pendidikan?

e. Bagaimana Sistem informasi perpustakaan dalam organisasi pendidikan?

\section{Tujuan}

Dari tujuan yang diuraikan di atas, dapat diambil tujuan dari artikel ini antara adalah:

a. Mengetahui Sistem informasi Akuntansi/Keuangan dalam organisasi pendidikan

b. Mengetahui Sistem Informasi Kepegawaian dalam organisasi pendidikan

c. Mengetahui Sistem Informasi Akademik/Kurikulum dalam organisasi pendidikan

d. Mengetahui Student Centered Learning melalui e-Learning dalam organisasi pendidikan

e. Mengetahui Sistem informasi perpustakaan dalam organisasi pendidikan

\section{Pembahasan}

Manajemen Sistem Informasi Pendidikan (MSIP) adalah sistem yang didisain untuk 
kebutuhan manajemen dalam upaya mendukung fungsi-fungsi dan aktivitas manajemen pada suatu organisasi pendidikan. Maksud dilaksanakannya MSIP adalah sebagai pendukung kegiatan fungsi manajemen ; planning, organizing, staffing, directing, evaluating, coordinating, dan budgeting dalam rangka menunjang tercapainya sasaran dan tujuan fungsi-fungsi operasional dalam organisasi pendidikan.

Dengan adanya MSIP organissi pendidikan akan merasakan beberapa manfaat sebagai berikut, pertama, tersedianya sistem pengeloaan data dan informasi pendidikan. Kedua, terintegrasinya data dan informasi pendidikan untuk mendukung proses pengambilan keputusan. Ketiga, tersedianya data dan informasi pendidikan yang lengkap bagi seluruh stakholders yang berkepentingan dalam bidang pendidikan.

MSIP digunakan oleh penggunanya sebagai alat bantu pengambil keputusan dan oleh pihak lain yang tergabung dalam interorganizational information system sehingga organisasi pendidikan dapat berinteraksi dengan pihak berkepentingan (stakeholders). Nilai penting MSIP adalah:

- $\quad$ Sistem Informasi yang berbasis computer (computer-based information sistems) memungkinkan pendelegasian kegiatan rutin.

- Teknologi informasi memungkinkan pengolahan data secara lebih akurat dan andal.

Pembuatan keputusan akan ditunjang dengan pilihan alternatif yang lebih objektif dengan data pendukung yang lengkap.

- Monitoring dan evaluasi memerlukan penyerapan informasi secara cepat dan efisien.

\section{A. Sistem Informasi Akuntansi/Keuangan Dalam Organisasi Pendidikan}

\section{Nugroho Widjajanto (2001)}

"Sistem Informasi Akuntansi (SIA) adalah susunan dari berbagai macam dokumen, catatan, peralatan termasuk komputer dan perlengkapannya, alat komunikasi, tenaga pelaksana serta seluruh laporan yang didesain untuk mentransformasikan data keuangan menjadi informasi yang dibutuhkan oleh manajemen".

\section{Bodnar dan Hopwood (2010)}

Sistem Informasi Akuntansi (SIA) adalah kumpulan dari berbagai macam sumber daya yaitu manusia dan juga peralatan yang memang dibuat untuk mengubah data keuangan dan juga data lainnya menjadi sebuah informasi yang berguna bagi penggunanya.

Sistem Informasi Akuntasi adalah pemrosesan data dan transaksi untuk menghasilkan informasi yang berguna bagi user dalam merencanakan, mengoperasikan dan mengendalikan keuangan organisasi.

Tiga fungsi penting SIA dalam Organisasi adalah :

1. Mengumpulkan dan menyimpan data tentang aktivitas-aktivitas yang dilaksanakan oleh organisasi agar pihak manajemen, pegawai dan pihak-pihak luar yang berkepentingan dapat meninjau ulang hal-hal yang telah terjadi 
2. Mengubah data menjadiinformasi yang berguna bagi pihak manajemen untuk membuat keputusan dalam aktivitas perencanaan, pelaksanaan dan pengawasan

3. Menyediakan pengendalian yang memadai untuk menjaga aset-aset organisasi termasuk data organisasi, untuk memastikan bahwa data tersebut tersedia dibutuhkan, akurat dan andal.

Bagaimana SIA dapat menambah nilai dalam organisasi bagi organisasi :

- Mengembangkan produk dan pelayanan dengan meningkatkan kualitas dan pengurangan biaya

- Meningkatkan efisiensi

- Memberikan inforasi yang tepat waktu dan reiabel untuk pengambilan keputusan

- Memberikan keuntungan kompetittif bagi perusahaan

- Meningkatkan komunikasi

- Meningkatkan penerapan pengetahuan (berbagi) penerapan

Data dan Informasi

- Data adalah fakta-fakta yang dikumpulkan, disimpan dan diproses dengan sistem informasi

- Informasi adalah data yang diorganisir/diatur, diberi arti dan data yang berguna

- Informasi disediakan untuk :

1. External User : Mandatory information (ex: tax report) Essential information (ex purchase order \& cust. Billing)

2. Internal User: discrectionary information (kebijaksanaan) more detail \&comlex report

\section{B. Sistem Informasi Kepegawaian Dalam}

\section{Organisasi Pendidikan}

Di dalam Keputusan Menteri Dalam Negeri N0.17tahun 2000 disebutkan bahwa: "Sistem Informasi Manajemen Kepegawaian (SIMPEG) merupakan suatu totalitas terpadu yang terdiri dari perangkat pengolah meliputi pengumpul prosedur, tenaga pengolah dan perangkat lunak, perangkat penyimpanan meliputi pusat data dan bank data serta perangkat komunikasi yang saling berkaitan, saling ketergantungan dan saling menentukan dalam rangka penyediaan informasi di bidang kepegawaian". Sama halnya dengan pendapat Mansur (2008) menyatakan bahwa: "Sistem informasi manajemen kepegawaian adalah sebuah sistem informasi terpadu, yang meliputi pendataan pegawai, pengolahan data, prosedur, tata kerja, sumber daya manusia, dan teknologi informasi untuk menghasilkan informasi yang cepat, lengkap dan akurat dalam rangka mendukung administrasi kepegawaian".

Selanjutnya Henry Simamora (2004: 90) mengemukakan bahwa: "Sistem informasi manajemen kepegawaian adalah prosedur sistematik untuk mengumpulkan, menyimpan, mempertahankan, menarik, dan memvalidasi data yang dibutuhkan oleh sebuah organisasi tentang sumber daya manusia, aktivitas-aktivitas personalia, karekteristik-karakteristik unit-unit organisasi". Menurut Me Leod dan G.Schell (2004: 475), Human Resourches Information System (HRIS) ini dalam Bahasa Indonesia dikenal dengan nama Sistem Informasi Manajemen Kepegawaian (SIMPEG), yaitu berkenaan dengan merancang format-format data kepegawaian dan mengatur sistem pengumpulan, pengolahan, penyimpanan dan pelaporan 
informasi kepegawaian yang terdiri dari data pegawai, data jabatan, data pendidikan, data penghargaan, data pendidikan dan pelatihan, data keluarga, data kehadiran dan Iain-lain, sehingga dapat dikelola informasi tentang perencanaan kebutuhan pegawai, penilaian kinerja, pembinaan dan pengembangan karirnya, kesejahteraan, serta pemberhentian atau kepensiunannya.

Tujuan utama sistem informasi manajemen kepegawaian (SIMPEG) ialah membantu proses manajemen pada suatu organisasi. Manajemen meliputi seluruh hierarki kepengurusan dalam suatu organisasi, dimulai dari hierarki manejemen puncak yang bertanggungjawab atas keberhasilan atau kegagalan organisasi secara keseluruhan hingga pada hierarki manajemen bawah yang hanya bertanggungjawab atas operasi sehari-hari dari departemen tertentu saja. Ada beberapa hal yang perlu dicatat dalam perkembangan konsep sistem informasi manajemen kepegawaian dalam lingkup administrasi negara. Pertama, terdapat begitu maraknya buku-buku sistem informasi manajemen kepegawaian (SIMPEG) yang mengakar sekaligus teraplikasi dalam bidang ekonomi yang telah lama dianggap menjadi bagian yang menyatu dalam pengajaran dan aplikasi pada administrasi negara khususnyapada penerapan model organisasi publik.

Perbedaan struktur dan manajemen pada sektor publik dan swasta menghendaki penerapan framework sistem informasi yang berbeda. Kedua, pengertian sistem informasi manajemen kepegawaian (SIMPEG) dalam penulisan ini akan digunakan dalam konteks, baik sistem, informasi, dan manajemen. Sehingga tidak dapat dikatakan bahwa seperangkat komputer itu adalah merupakan satu hal yang dapat dikatakan sebagai konsep sistem informasi manajemen sebagaimana yang terdapat dalam beberapa majalah, harian, atau iklan-iklan, atau bahkan dalam beberapa pidato dari pejabat pemerintah dalam kaitannya dengan perkembangan teknologi yang dikacaukan dengan konsep sistem informasi manajemen secara menyeluruh. Perkembangan teknologi komputer hanyalah salah satu instrumen untuk mengolah data dalam sistem informasi manajemen, dan hal itu baru merupakan konsep sistem informasi manajemen kalau dikaitkan dengan proses pembuatan keputusan dalam organisasi (publik).

Pada umumnya SIMPEG mencakup proses yang berkaitan dengan perencanaan pegawai, administrasi pegawai, evaluasi kinerja pegawai, pendidikan dan pelatihan, dan pensiun. Perencanaan Pegawai merupakan suatu proses analisis dan simulasi kebutuhan pegawai yang dimiliki organisasi dikaitkan dengan pengembangan kegiatan di masa mendatang yang berkaitan dengan pengadaan dan penempatan pegawai. Proses perencanaan pegawai mencakup antara lain pembuatan rekapitulasi untuk analisis dan simulasi yang diolah dari data kepegawaian untuk memperoleh gambaran kekuatan sumberdaya manusia yang dimiliki, proses pengadaan pegawai atau rekruitmen yang pada dasarnya merupakan pengumpulan biodata dan proses alokasi yaitu dengan data yang dimiliki dapat dilakukan 
analisis kebutuhan penempatan pegawai ke posisi yang lebih tepat.

\section{Sistem Informasi Akademik/Kurikulum Dalam Organisasi Pendidikan}

Pendidikan berbasis kompetensi menekankan pada kemampuan yang harus dimiliki oleh lulusan suatu jenjang pendidikan. Kompetensi yang sering disebut dengan standar kompetensi adalah kemampuan yang harus dikuasai oleh lulusan. Kemampuan ( kompetensi ) lulusan merupakan modal utama untuk bersaing di tingkat global, karena persaingan yang terjadi adalah pada kemampuan sumber daya manusia. Oleh karena itu, penerapan pendidikan berbasis kompetensi diharapkan akan menghasilkan lulusan yang mampu berkompetisi di tingkat nasional, regional dan global. Implikasi penerapan pendidikan berbasis kompetensi adalah pengembangan silabus dan sistem pengujian berdasarkan kemampuan dasar.

Silabus merupakan acuan untuk merencanakan dan melaksanakan program pembelajaran, sedangkan sistem pengujian berbasis kemapuan dasar mencakup jenis ujian, bentuk soal, dan pelaksanaannya. Jenis ujian adalah berbagai bentuk tagihan seperti ulangan atau tugas-tugas yang harus dikerjakan oleh siswa. Bentuk soal terkait dengan jawaban yang harus dilakukan oleh siswa seperti isian singkat, pilihan ganda, uraian dan sebagainya. Kemampuan dasar adalah bagian dari standar kompetensi. Jadi standar kompetensi terdiri atas sejumlah kemampuan dasar. Kemampuan dasar adalah kemampuan minimum dalam mata pelajaran /bidang studi yang harus dikuasai oleh siswa.

Gambaran umum:

1. Sistem informasi akademik adalah modul aplikasi sebagai tools dalam melakukan pengelolaan administrasi pendidikan dan data akademik .

2. Kemudahan-kemudahan yang dihimpun di Sistem Informasi Akademik Gamatechno ini memungkinkan diakses dari mana saja melalui internet browser dan overall akan membantu operator/staf administrasi dalam kegiatan kesehariannya.

\section{Mengetahui Student Centered Learning Melalui E-Learning Dalam Organisasi Pendidikan}

Hartley yang menyatakan e-learning merupakan suatu jenis belajar mengajar yang memungkinkan tersampaikannya bahan ajar ke siswa dengan menggunakan media internet. Internet atau media jaringan komputer lain.

Manfaat e-learning :

1) Menghemat waktu proses belajar mengajar

2) Mengurangi biaya perjalanan

3) Menghemat biaya pendidikan secara keseluruhan

4) Melatih pembelajar lebih mandiri dan medapatkan ilmu pengetahuan

Student Centered Learning (SCL) merupakan metode pembelajaran dengan karakteristik berpusat pada siswa. Metode ini memberikan otonomi dan pembelajaran yang lebih baik pada siswa. Pada SCL, siswa ikut serta dalam menentukan input materi, metode serta waktu pembelajaran dengan disetujui oleh 
administrator. Guru berperan sebagai penunjang dan dapat menerima kritik/saran dari para siswanya.

Di Indonesia, SCL belum banyak dipakai. Metode yang dipakai di Indonesia cenderung Teacher Centered Learning (TCL) yang bersifat satu arah.

\section{E. Mengetahui Sistem informasi perpustakaan dalam organisasi pendidikan}

Sistem informasi perpustakaan dikembangkan dari pemikiran dasar bagaimana kita melakukan otomatisasi terhadap berbagai business dalam suatu perpustakaan. SIPERPUS merupakan sebuah sistem yang terintegrasi untuk menyediakan informasi guna mendukung operasi, manajemen dan fungsi pengambilan keputusan dalam perpustakaan.

Sistem informasi perpustakaan (SIPERPUS) merupakan perangkat lunak yang didesain khusus untuk mempermudah pendataan koleksi perpustakaan, katalog, dan anggota/ peminjam, transaksi dan sirkulasi koleksi perpustakaan.

Keseluruhan bekerja secara sistematis sehingga dapat memperbaiki administrasi dan operasional perpustakaan serta dapat menghasilkan bentuk-bentuk laporan yang efektif dan berguna bagi manajemen perpustakaan.

SIPERPUS yang kami rancang terdiri dari berbagai versi. Sistem sudah dilengakapi dengan fasilitas BARCODE READER yang akan mempercepat proses trasaksi operasional perpustakaan.

SIPERPUS yang dirancang merupakan sistem informasi berbasis web dengan bahasa pemograman dan database yang bersifat open source/free, di mana user/klien kami tidak perlu lagi membeli software-software pendukung guna mengaplikasikan SIPERPUS tersebut.

\section{KESIMPULAN DAN SARAN Kesimpulan}

Manajemen Sistem Informasi Pendidikan (MSIP) adalah sistem yang didisain untuk kebutuhan manajemen dalam upaya mendukung fungsi-fungsi dan aktivitas manajemen pada suatu organisasi pendidikan Wilayah garapan/pokok-pokok Menajemen Sistem Informasi Pendidikan (MSIP) meliputi ; a.Sistem informasi Akuntansi/Keuangan b.Sistem Informasi Kepegawaian c.Sistem Informasi Akademik/Kurikulum d.Student Centered Learning melalui e-Learning e.Sistem informasi perpustakaan

\section{Saran}

Kita sebagai pendidik harus memanfaatkan MSIP dengan sebaik-baiknya untuk perkembangan pendidikan. Menggunakan MSIP dengan tepat dan akurat untuk kemajuan pendidikan

\section{DAFTAR PUSTAKA}

http://visiquantum.blogspot.com/2008/08/manaje men-sistem-informasi-pendidikan.html. $\neg$ Boediono. 1998. Panduan Manajemen Sekolah. Direktorat Pendidikan Menengah Umum $\neg$ Wahyu widyaningsih.ayukw2.muliply.com $\neg$ WWW.Air Media Persada.com $\neg$ WWW. Wikipedia bahasa Indonesia, ensiklopedia bebas.co.id $\neg$ WWW.scribd.com/doc/3365808/PembelajaraneLearning $\neg$ http://ilmutuhan.blogspot.co.id/2010/08/manaje men-sistem-informasi-dalam.html Agustriandra,V,Sabandi,A (2019) Persepsi guru terhadap penerapan SIM akademik di SMKN 3 Padang 